\title{
Grain quality of maize hybrids submitted to different sowing times and nitrogen rates
}

\author{
Qualidade de grãos de híbridos de milho submetidos em diferentes épocas de semeadura e doses \\ de nitrogênio
}

\author{
Juliano Berghetti*, Ricardo Trezzi Casa, Antônio Eduardo Coelho, Luís Sangoi, Fabio Nascimento da \\ Silva, Bruno Tabarelli Scheidt, Flávio Chupel Martins, André Henrique Ludwig
}

Universidade do Estado de Santa Catarina, Lages, SC, Brasil. *Autor para correspondência: julianoberghetti@yahoo.com.br.

Submission: 01/02/2019 / Acceptance: 10/12/2019

\begin{abstract}
Grain quality is essential in the food industry, and it shows variations depending on crop management conditions in the field. The objective of this study was to quantify the effect of hybrids, sowing seasons, and topdressing nitrogen rates on the incidence of damaged grains and their correlation with pathogenic fungi. The experiment was conducted under field conditions in Atalanta, Santa Catarina, Brazil, in a split split-plot randomized block design consisting of the AG9025 PRO3 (super-early) and 30F53 VYH (early) hybrids, preferential (September 20) and late (December 5) sowing season, and nitrogen rates $(0,150$, 300 , and $450 \mathrm{~kg} \mathrm{ha}^{-1}$ ). The percentage of normal, fermented, and burned grains, as well as the incidence of fungi in grains, were quantified. The hybrid 30F53 VYH had shown the lowest percentage of fermented grains (8.4\%) when compared to the hybrid AG9025 PRO3 (43.2\%). No significant difference was observed between the sowing season for fermented grains. The hybrid AG9025 PRO3 had shown an increase in fermented grains with nitrogen addition, while the hybrid 30F53 VYH presented a stable behavior. The hybrid AG9025 PRO3 (35.5\%) showed the lowest incidence of Fusarium verticillioides in the grains when compared to the hybrid 30F53 VYH (49.9\%). The fungus incidence was also lower in the preferential sowing season (35.7\%) than in the late one (49.7\%). The hybrid AG9025 PRO3 maintained the percentage of fungus incidence stable as a function of nitrogen rates. No significant correlation was observed between the percentage of normal and fermented grains with the incidence of $F$. verticillioides.
\end{abstract}

KEYWORDS: Zea mays, damaged grains, Fusarium verticillioides, nitrogen fertilization.

\section{RESUMO}

A qualidade dos grãos é essencial na indústria alimentícia e mostra variações dependendo das condições de manejo da cultura no campo. O objetivo deste estudo foi quantificar o efeito de híbridos, épocas de semeadura e doses de nitrogênio em cobertura sobre a incidência de grãos avariados e sua correlação com fungos patogênicos. $O$ experimento foi conduzido em condições de campo, em Atalanta, Santa Catarina, Brasil, em delineamento de blocos ao acaso, em parcelas sub-subdivididas, constituído pelos híbridos AG9025 PRO3 (super-precoce) e 30F53 VYH (precoce), semeadura preferencial (20 de setembro) e tardia (5 de dezembro) e doses de nitrogênio em cobertura $\left(0,150,300\right.$ e $\left.450 \mathrm{~kg} \mathrm{ha}^{-1}\right)$. $O$ percentual de grãos normais, fermentados e avariados, bem como a incidência de fungos em grãos, foram quantificados. O híbrido 30F53 VYH apresentou o menor percentual de grãos fermentados $(8,4 \%)$ quando comparado ao híbrido AG9025 PRO3 (43,2\%). Nenhuma diferença significativa foi observada entre as épocas de semeadura nos grãos fermentados. O híbrido AG9025 PRO3 apresentou um aumento nos grãos fermentados com adição de nitrogênio, enquanto o híbrido 30F53 VYH apresentou comportamento estável. O híbrido AG9025 PRO3 (35,5\%) apresentou a menor incidência de Fusarium verticillioides nos grãos quando comparado ao híbrido 30F53 VYH (49,9\%). A incidência do fungo foi menor também na época de semeadura preferencial $(35,7 \%)$ em relação à tardia (49,7\%). O híbrido AG9025 PRO3 manteve estável a porcentagem de incidência de fungos em função das doses de nitrogênio. Nenhuma correlação significativa foi observada entre a porcentagem de grãos normais e fermentados com a incidência de $F$. verticillioides.

PALAVRAS-CHAVE: Zea mays, grãos danificados, Fusarium verticillioides, adubação nitrogenada. 


\section{INTRODUCTION}

The nutritional composition of maize grains makes this cereal widely used as a human and animal energy source. The occurrence of fungi causing ear rot may directly affect the grains, changing their form from normal to damaged (sum of burned, fermented, moldy, chalky, and germinated grains), reducing their quality. Burned grains are lighter, and they, therefore, interfere negatively with productivity, besides presenting a low nutritional value. Fusarium verticillioides (Sacc.) Nirenberg (Fusarium ear rot), $F$. graminearum Schwabe (Gibberella ear rot), and Stenocarpella macrospora Earle and S. maydis Berk (Diplodia ear rot) are the fungi commonly found in maize grains (MARIO et al. 2003, RIBEIRO et al. 2005, NERBASS et al. 2015), resulting from colonization during grain formation until physiological maturity. Under conditions above normal rainfall, during the stages of pollination and grain formation, there is usually an increase in ear rot, affecting quality and fungi associated with grains (REID et al. 1999). Fungal infection is also favored by conditions where grain moisture content is above $20 \%$, that is, when ears have poor husk formation and insect damage (PINTO 2005). Due to the presence of these fungi, mainly of the genus Fusarium, the production of mycotoxins can occur (ALEXANDER et al. 2011), harming animal and human health.

In Brazil, maize has been predominantly cultivated in no-tillage areas, in which the decomposition of crop residues on the soil surface is slower, benefiting the survival, sporulation, dispersion, and inoculation of necrotrophic agents responsible for ear rot and damaged grains (CASA et al. 2003, REIS et al. 2011). Crop rotation is an important control measure for these pathogens (DENTI \& REIS 2001, TRENTO et al. 2002). However, some plant species cultivated before maize in annual crop rotation may have effects such as wheat, oat, barley, and ryegrass cultivated in the winter, which are hosts of $F$. graminearum (CASA et al. 2007, REIS et al. 2011), and soybean cultivated in the summer, host of $F$. graminearum and $F$. verticillioides (RANZI et al. 2017). The other management alternatives to minimize the occurrence of damaged grains are related to the adequacy of plant density (TRENTO et al. 2002, CASA et al. 2007), use of resistant genotypes (NERBASS et al. 2015, PEREIRA FILHO \& BORGHI 2016), and fungicide applications (JULIATTI et al. 2007, DUARTE et al. 2009, ANDRIOLLI et al. 2016).

Plant nutrition and climatic conditions may also influence grain quality. Nonetheless, these factors are little investigated in the management of ear diseases. Sowing season (SS) affects crop behavior during its reproductive stage. It interferes mainly on the dynamics of grain moisture loss, influencing the fungus infection process. According to COELHO et al. (2019), when the sowing date of maize is postponed from the beginning to the end of spring, using very early hybrids, there is an increase in the incidence of stalk rot, ear rot, and burned grains. In late sowings, the grain filling occurs under low air temperature and small solar radiation availability. Such conditions delay the loss of moisture, favoring the occurrence of ear rots (SANGOI et al. 2010). WORDELL FILHO \& SPAGNOLLO (2013) also attributed the higher incidence of burned grains to environmental factors. However, they did not observe clear trends related to the hybrid cycle, $\mathrm{N}$ rate, and ear diseases. In this context, this study aimed to quantify the incidence of damaged grains and their correlation with pathogenic fungi as affected by hybrid cycle, SS, and nitrogen side-dress rates.

\section{MATERIAL AND METHODS}

The field experiment was carried out in 2016 and 2017 in Atalanta, Santa Catarina, Brazil, at the geographical coordinates $27^{\circ} 26^{\prime} 03^{\prime \prime} \mathrm{S}$ and $49^{\circ} 42^{\prime} 06^{\prime \prime} \mathrm{W}$, with an altitude of $586 \mathrm{~m}$. The regional climate is a humid mesothermal subtropical one with warm summers. The soil of the experimental area is classified as Dystrudept (Cambissolo Haplico distrófico, according to the Brazilian Soil Classification System).

The experimental design was a split-split-plot randomized block design with four replications with plots consisting of the AG9025 PRO3 (single hybrid, super-early, with yellow and dent grain) and 30F53 VYH (single hybrid, early, with semi-flint orange grain) hybrids, subplots consisting of preferential sowing season (PSS) on September 20 and late sowing season (LSS) on December 5, and sub-subplots consisting of four topdressing $\mathrm{N}$ rates, i.e., $0,150,300$, and $450 \mathrm{~kg} \mathrm{~N}^{-1}$ equivalent to $0,0.5,1.0$, and 1.5 times the additional rate for an expected grain yield of $21,000 \mathrm{~kg} \mathrm{ha}^{-1}$, respectively. Base fertilization was performed in the sowing rows for the same expected grain yield, consisting of $30 \mathrm{~kg} \mathrm{~N} \mathrm{ha}^{-1}, 300 \mathrm{~kg} \mathrm{P}_{2} \mathrm{O}_{5} \mathrm{ha}^{-1}$, and $200 \mathrm{~kg} \mathrm{~K}_{2} \mathrm{O}$ $\mathrm{ha}^{-1}$, according to crop requirements.

Sowing was carried out using manual seeders in a no-tillage system under a sequence of crops characterized by monoculture in the winter season (the previous two years with black oat cultivation) and crop rotation in the summer (the last two years with soybean cultivation). Three to four seeds were distributed linearly and equidistantly at each pit, with a space of $0.7 \mathrm{~m}$ between rows. Thinning was carried out at the V2 (two fully expanded leaves) stage of the RITCHIE et al. (1993) scale to reach a population of 


\section{5,000 plants ha ${ }^{-1}$.}

Topdressing $\mathrm{N}$ rates as urea $(45 \% \mathrm{~N})$ were applied. Treatments had their respective rates split in equal proportion at the stages $\mathrm{V} 4, \mathrm{~V} 8$, and $\mathrm{V} 12$ (4, 8, and 12 fully expanded leaves, respectively), except for the control (without $\mathrm{N}$ ). Each experimental unit (sub-subplot) had dimensions of $2.8 \times 6 \mathrm{~m}$ and was composed of four rows, being the two central rows (64 plants) considered as the useful area and the two external rows as borders.

Seeds were treated with carbendazim $\left(0.45 \mathrm{~g}\right.$ a.i. $\left.\mathrm{kg}^{-1}\right)+$ thiram $\left(1 \mathrm{~g}\right.$ a.i. $\left.\mathrm{kg}^{-1}\right)$ and metalaxyl-M $(0.015 \mathrm{~g}$ a.i. $\left.\mathrm{kg}^{-1}\right)+$ fludioxonil $\left(0.038 \mathrm{~g}\right.$ a.i. $\left.\mathrm{kg}^{-1}\right)$. Weed control was performed with atrazine $\left(1.5 \mathrm{~kg}\right.$ a.i. ha $\left.{ }^{-1}\right)+$ metolachlor (1.7 g a.i. ha $\left.^{-1}\right)$ following sowing and tembotrione $\left(100 \mathrm{~g}\right.$ a.i. ha $\left.{ }^{-1}\right)$ at $\mathrm{V} 3$, aiming at avoiding competition with the crop. Fall armyworm (Spodoptera frugiperda) was preventively controlled with lambdacyhalothrin $\left(6 \mathrm{~g}\right.$ a.i. $\left.\mathrm{ha}^{-1}\right)+$ chlorantraniliprole $\left(12 \mathrm{~g}\right.$ a.i. $\left.\mathrm{ha}^{-1}\right)$, in two opportunities supported by the technologies PRO and Leptra of hybrids AG9025 PRO3 and 30F53 VYH, respectively, maintaining leaf area intact. No fungicide application was carried out.

The harvest was performed manually when the grains had between $18 \%$ and $22 \%$ moisture content, 15 days after the $\mathrm{R} 6$ stage (physiological maturity). After the trail, the weight of the one-thousand grains was assessed for each experimental unit, the yield was determined, and 250 grams of grains were collected, classified as burned, fermented, and normal. After weighing, their respective percentage values following I.N. 60/2011 (MAPA 2011) were attributed.

From each sample of $250 \mathrm{~g}$ (homogeneous mixture), 200 grains were divided into 4 replications of 50 grains for laboratory analysis of pathology. These grains were disinfected in sodium hypochlorite solution $(1 \%)$ for two minutes. Excess solution was removed by washing with sterile distilled water followed by drying the grains on filter paper. Then, in a flow chamber, 25 grains were arranged per acrylic box $(11 \times 11 \times 3.5$ $\mathrm{cm})$ previously sterilized with alcohol $(70 \%)$ and containing PDA+A (potato-dextrose-agar + the antibiotic streptomycin sulfate at a rate of $200 \mathrm{mg} \mathrm{L}^{-1}$ ). These boxes were maintained in a growth chamber with a temperature of $23 \pm 2{ }^{\circ} \mathrm{C}$ and a 12-hour photoperiod for 7 days. We considered as infected the grains on which one or more colonies or structures of the fungi were identified under a stereoscopic microscope at $40 \mathrm{x}$ magnification. The presence of fungi was confirmed in a slide under a light microscope by analyzing fungal structures and comparing them with those described in the literature (BARNETT \& HUNTER 1998, WHITE 1999).

The data were submitted to analysis of variance in a split-plot scheme by the F-test at $\mathrm{F}<0.05$ error probability. When significant, Tukey's test at $p<0.05$ error probability was used for qualitative variables and the regression analysis for nitrogen side-dress rates. The Pearson correlation coefficient between normal, fermented, and burned grains with the incidence of $F$. verticillioides, thousand-grains weight (TGW), and yield was determined with the software SAS 9.1 (SAS Institute, Cary, NC, USA) and the other analyses with the statistical software SISVAR 5.6 (FERREIRA 2011).

\section{RESULTS AND DISCUSSION}

No shriveled, germinated, and moldy grains were observed. Chalky grains were included with those fermented because they presented both characteristics, as suggested by I.N. 60/2011 (MAPA 2011).

A significant interaction was observed between $\mathrm{N}$ rates and hybrids for the percentage of normal and fermented grains. The percentage of burned grains presented an interaction between hybrids and SS, also being responsive to $\mathrm{N}$ rates. PSS showed $71.9 \%$ of normal grains, differing statistically from LSS, which showed a value of $74.9 \%$. No significant difference was observed between SS for fermented grains, with values of $24.7 \%$ in PSS and $26.9 \%$ in LSS.

No significant difference in the percentage of burned grains among hybrids was observed in PSS. This variable also did not differ for the hybrid 30F53 VYH concerning the different SS, differing only for the hybrid AG9025 PRO3, which changed from $0.4 \%$ of burned grains in PSS to $1.74 \%$ in LSS (Table 1 ).

Table 1. Interaction between hybrids and sowing times for the percentage of burned grains. Atalanta, SC.

\begin{tabular}{lcl}
\hline \multirow{2}{*}{ Variables } & Burned grains (\%) & \\
\cline { 2 - 3 } & Preferential seeding & Late sowing \\
AG9025 PRO3 & $0.4 \mathrm{a} \mathrm{B}^{*}$ & 1.7 a A \\
30F53 VYH & $0.5 \mathrm{a} \mathrm{A}$ & $0.7 \mathrm{~b} \mathrm{~A}$ \\
\hline
\end{tabular}

*Means followed by distinct letters, upper case in the row and lowercase in the column differ statistically. 
et al. 2005, NERBASS et al. 2015). Although both materials are single hybrids, AG9025 PRO3 is a superearly, and 30F53 VYH is an early hybrid, and deficient husk formation is a characteristic observed in higher precocity hybrids, exposing grains directly to the environment and pathogens, which occurs in a lower proportion in higher cycle hybrids (PANISON et al. 2016).

Stability was observed in the percentage of normal and fermented grains for the hybrid 30F53 VYH as a function of $\mathrm{N}$ rates (Figure $1 \mathrm{a}$ and $1 \mathrm{~b}$ ). However, the hybrid AG9025 PRO3 showed a consistent response to rate increments, with a coefficient of determination $\left(R^{2}\right)$ above $90 \%$ for a linear increase in fermented grains and a linear decrease in normal grains as $\mathrm{N}$ rates increased. In the average of SS and $\mathrm{N}$ rates, the hybrid AG9025 PRO3 presented $55.7 \%$ of normal grains and $43.2 \%$ of fermented grains when compared to the hybrid 30F53 VYH, which presented, respectively, 91.1 and $8.4 \%$.

(a)

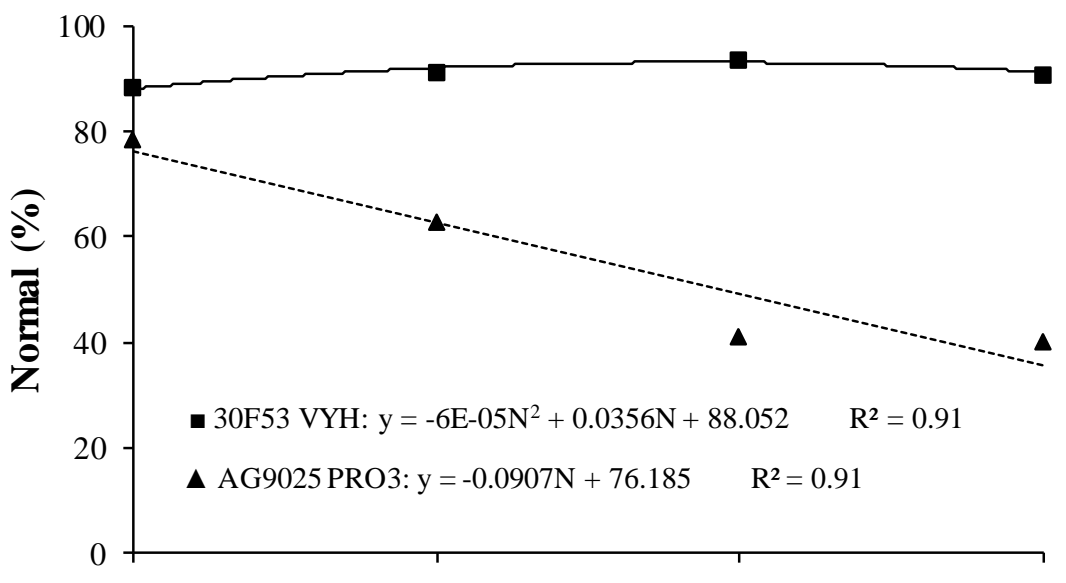

(b)

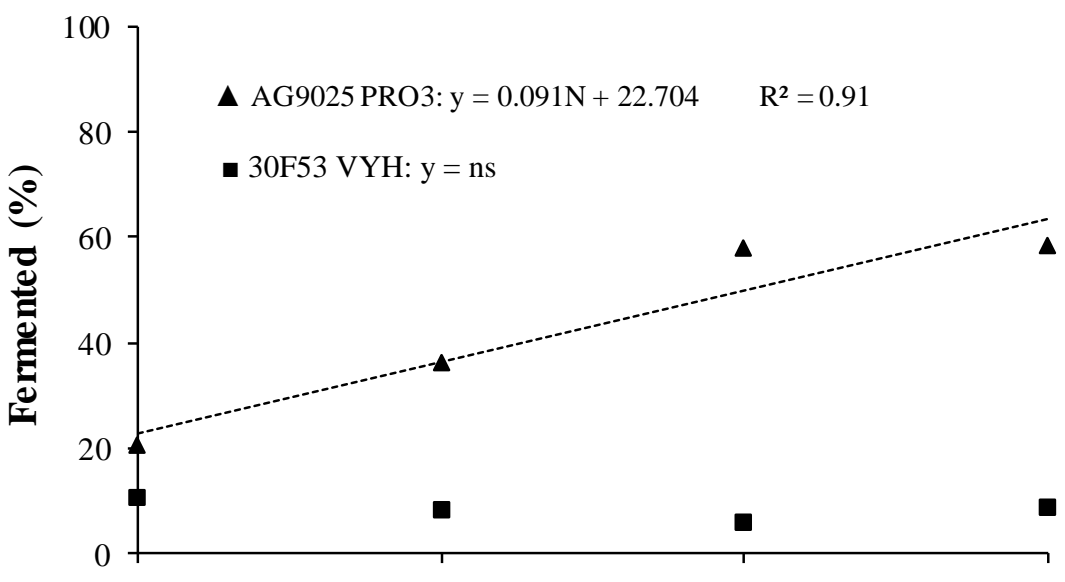

(c)

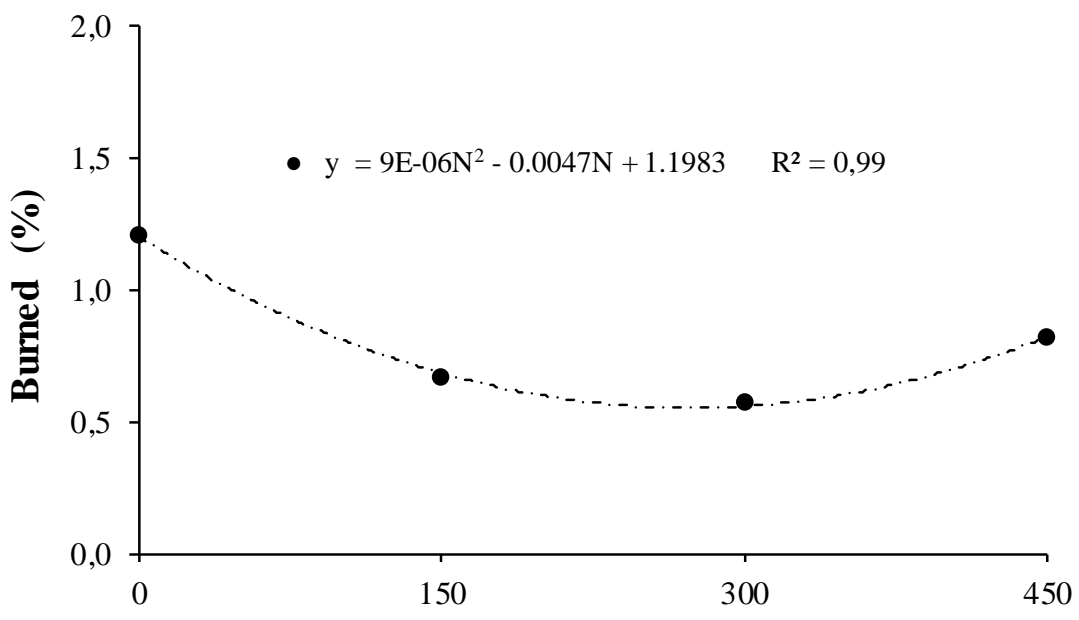

$\mathrm{N}$ rates (kg ha-1)

Figure 1. Regressions of the interaction between $\mathrm{N}$ rates and hybrids for percentage of normal grains (a), fermented (b) and burned (c). ns: not significant. Atalanta, SC. 
For burned grains, a significant effect was observed for $\mathrm{N}$ rates (Figure 1c). However, the behavior of $\mathrm{N}$ rates for hybrids did not differ as occurred for the percentage of normal and fermented grains. A decrease in the percentage of burned grains was initially observed as a function of $\mathrm{N}$ rate addition. Still, with a significant quadratic behavior, the percentage returned to an increase in the higher rates. COELHO et al. (2019) observed this quadratic behavior compared to $\mathrm{N}$ rates in monoculture hybrids cultivation, where the rate extremes presented the highest percentages of burned grains. DORDAS (2008) suggested that the increase in $\mathrm{N}$ rate promotes biochemical and physiological changes in the plant, increasing the content of organic compounds of low molecular weight, which are used as substrates for parasites. However, the quality of grains will not always be affected by the presence of pathogens. The increase of $\mathrm{N}$ rates can enhance ear growth, generating a husk coverage deficiency at the tip of the ear, exposing some grains to climatic oscillations. Such exposition may justify the higher occurrence of fermented and burned grains.

Concerning grain pathology, the fungus $F$. verticillioides predominated with $97.2 \%$ in relation to $1.4 \%$ of $F$. graminearum and $1.4 \%$ of $S$. macrospora in the general average of the assessed variables. The incidence of $F$. graminearum and $S$. macrospora was lower than $0.7 \%$, which is insufficient to generate any concrete results concerning the comparison of the sources of variation. In this sense, the subsequent statistical analyses were performed only for $F$. verticillioides.

For the variables, a significant difference was observed between hybrids and between sowing seasons, with no interaction between them. A significant response was observed for topdressing $\mathrm{N}$ addition, as well as between $\mathrm{N}$ rates and hybrids.

The hybrid AG9025 PRO3 presented an incidence of $F$. verticillioides of $35.5 \%$, which is $14.4 \%$ lower than that observed for the hybrid 30F53 VYH, with $49.9 \%$. In turn, PSS (35.7\%) also presented an incidence of fungus $14 \%$ lower in relation to LSS $(49.7 \%)$. The fungus $F$. verticillioides has a systemic transmission capacity for the ears from seeds and stalk (WILKE et al. 2007). The fungus may also infect ears through stigma or injuries (MUNKVOLD \& DESJARDINS 1997, POULSEN HORNUM et al. 2013). The transgenesis present in the tested hybrids, as well as chemical control, maintained spikes free from damage caused by caterpillars, thus discarding this infection route.

The hybrid 30F53 VYH has a longer cycle than that of AG9025 PRO3 and hence also has a more extended period of exposure of stigmas for pollination, and a higher predisposition for fungus infection may occur. This cycle difference is also visible in grain filling, in which hybrids with later cycles have grains moistened for a longer period, which, associated with husk formation, create a wet chamber, favoring grain infection and colonization. In this sense, SS may also influence this process since, in PSS, the reproductive period of the crop coincides with the months of higher solar radiation availability, generating higher temperatures (Figure 2) and lower relative air humidity. However, in LSS, the reduction in solar radiation availability due to a lower photoperiod leads to a decrease in temperature and consequently maintains a higher relative air humidity. With a higher relative air humidity, moisture loss from grains to the atmosphere is lower. In this case, in addition to delaying grain filling in LSS as a function of temperature decrease, grains maintain a higher percentage of moisture, which favors fungus infection and colonization.

The incidence of $F$. verticillioides in grains presented interaction between $\mathrm{N}$ rates and hybrids (Figure 3). The hybrid $30 \mathrm{~F} 53 \mathrm{VYH}$ significantly increased fungus incidence from 0 to $150 \mathrm{~kg} \mathrm{~N}^{-1}$, from which the increment was lower. The hybrid AG9025 PRO3 maintained the percentage of incidence stable as $\mathrm{N}$ rates increased, with no significant response to $\mathrm{N}$. The lowest incidence of $F$. verticillioides at $0 \mathrm{~kg} \mathrm{~N}^{-1}$ for the hybrid 30F53 VYH is related to the early senescence of leaves in plants with $\mathrm{N}$ deficiency, which leads to an early physiological maturity in relation to plants without deficiency. In this case, grain loses moisture and reaches its integral form early with a rigid tegument, becoming less predisposed to infections. When there is a supply of $\mathrm{N}$, plant follows its normal cycle, with small variations among rates, justifying the close values of incidence in the rates of 150,300 , and $450 \mathrm{~kg} \mathrm{~N}^{-1}$. The early hybrid $30 \mathrm{~F} 53 \mathrm{VYH}$ tends to have a longer cycle with $\mathrm{N}$ addition when compared to AG9025 PRO3, which leads to a higher infection.

No significant correlation was observed between normal and fermented grains with the incidence of $F$. verticillioides (Table 2). Fungus incidence was only correlated with the percentage of burned grains of the hybrid 30F53 VYH in PSS, with a significant value of $-69 \%$. Both results indicate the non-relationship between fungus presence in the grains with color characteristics that classify them as fermented and burned. In this sense, it is hypothesized that fermented grains may be caused by a change in the dynamics of the source-drain movement, production of plant defense compounds promoted by different $\mathrm{N}$ rates, or simply by genetic characteristics of the hybrid. The fungus may be infecting the grains without an apparent symptom of deterioration. In conclusion, YATES et al. (2005) found that the vegetative growth and grain yield of maize plants grown from seeds inoculated with $F$. verticillioides were equal to or greater than plants grown from 
uninoculated seeds, indicating that the fungus presence does not always cause damage. SARTORI et al. (2004) and RAMOS et al. (2014) have reported the transmission of infected seed fungi to seedlings, but no reductions in the percentage of germination were detected.

(a)
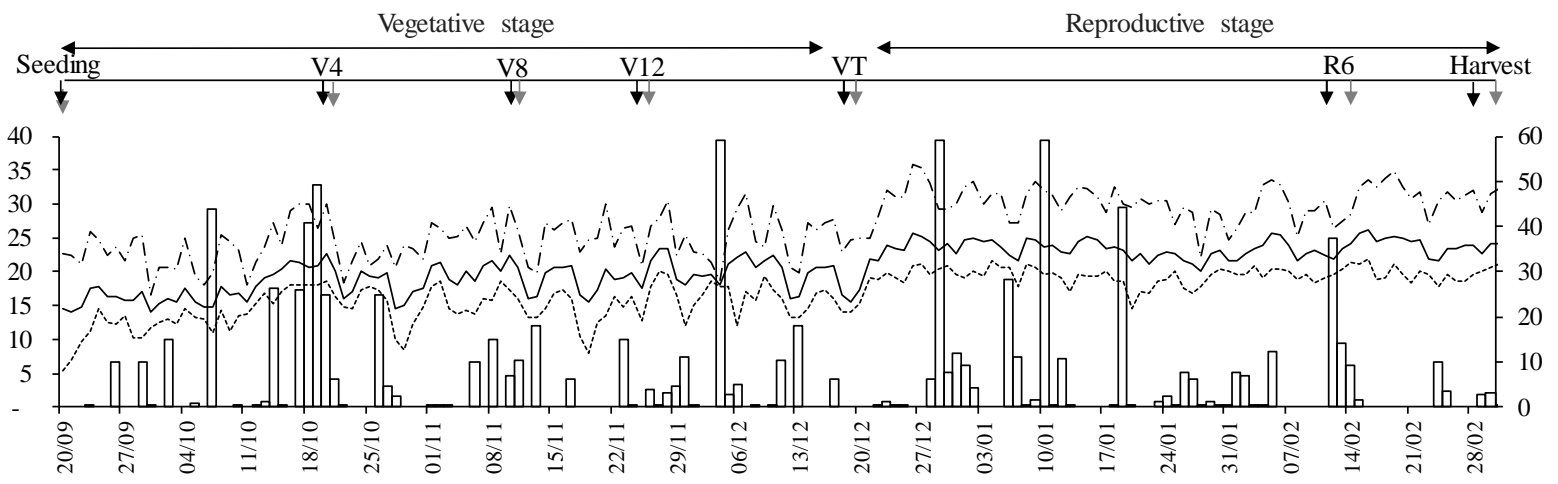

(b)

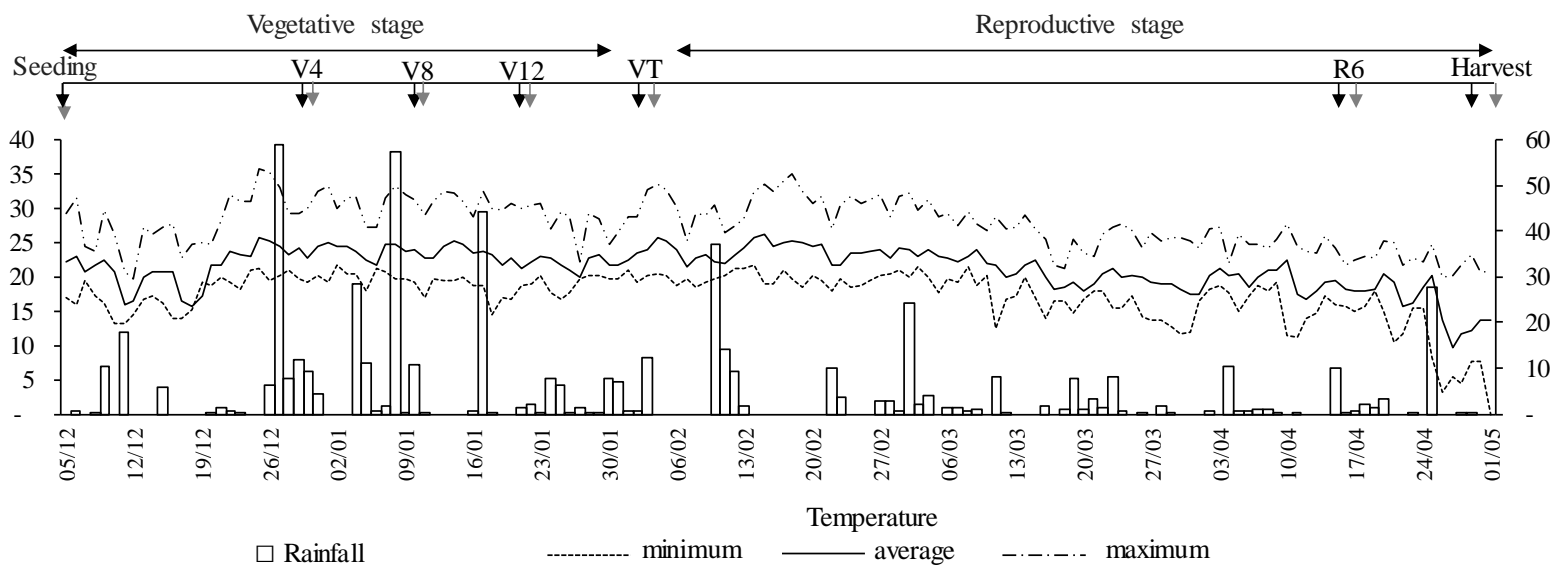

Figure 2. Daily temperature data in ${ }^{\circ} \mathrm{C}$ (rows) in the left session, and precipitation in $\mathrm{mm}$ (bars) in the right session, during maize crop cycles at preferential (a) and late (b) sowing seasons. Black arrows indicate the hybrid AG9025 PRO3 and ashes indicate 30F53 VYH. Atalanta, SC, data for 2016 and 2017.

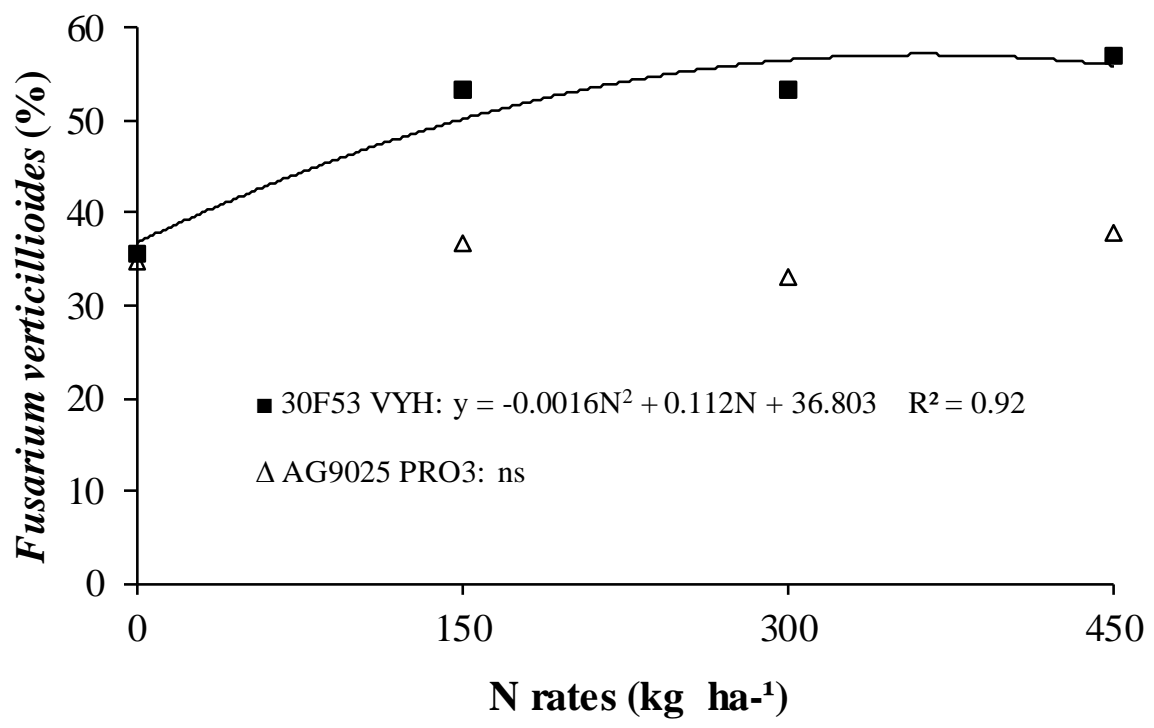

Figure 3. Regression of interaction of $\mathrm{N}$ rates and hybrids for the percentage of Fusarium verticillioides fungus in grains. ns: not significant. Atalanta, SC.

A significant and positive correlation was observed between the percentage of fermented grains and TGW and yield for the hybrid AG9025 PRO3 either in PSS or LSS (Table 2). The values of correlation between the percentage of fermented grains and yield ranged from $87 \%$ in LSS to $92 \%$ in PSS, and Rev. Ciênc. Agrovet., Lages, SC, Brasil (ISSN 2238-1171) 
percentage of fermented grains and TGW from $86 \%$ in LSS to $95 \%$ in PSS for the hybrid AG9025 PRO3 indicate that an increase in TGW and yield also increases the percentage of fermented grains. This behavior is intrinsically linked to $\mathrm{N}$ rates, and yield losses due to fermented grains for the hybrid AG9025 PRO3 are superimposed by the effect of $\mathrm{N}$ to yield increase.

Table 2. Coefficient of correlation between percentage of normal grains, fermented and burned and the variables incidence of Fusarium verticillioides, thousand-grains weight (TGW) and yield grains. Atalanta, SC.

\begin{tabular}{ccccc}
\hline Hybrid and season & Classification & F. verticillioides & TGW & Yield \\
\hline \multirow{2}{*}{ AG9025 PRO3 PSS } & Normal & $-0.07 \mathrm{~ns}$ & $-0.95^{* *}$ & $-0.91^{* *}$ \\
& Fermented & $0.07 \mathrm{~ns}$ & $0.95^{* *}$ & $0.92^{* *}$ \\
& Burned & $-0.23 \mathrm{~ns}$ & $-0.15 \mathrm{~ns}$ & $-0.25 \mathrm{~ns}$ \\
\hline \multirow{2}{*}{ AG9025 PRO3 LSS } & Normal & $-0.06 \mathrm{~ns}$ & $-0.85^{* *}$ & $-0.86^{* *}$ \\
& Fermented & $0.06 \mathrm{~ns}$ & $0.86^{* *}$ & $0.87^{* *}$ \\
& Burned & $-0.14 \mathrm{~ns}$ & $-0.35 \mathrm{~ns}$ & $-0.50^{*}$ \\
\hline \multirow{2}{*}{ 30F53 VYH PSS } & Normal & $0.30 \mathrm{~ns}$ & $0.60 *$ & $0.65^{* *}$ \\
& Fermented & $-0.20 \mathrm{~ns}$ & $-0.51 *$ & $-0.55^{*}$ \\
\hline \multirow{2}{*}{ 30F53 VYH LSS } & Burned & $-0.69 * *$ & $-0.82^{* *}$ & $-0.92^{* *}$ \\
& Normal & $0.01 \mathrm{~ns}$ & $0.12 \mathrm{~ns}$ & $0.26 \mathrm{~ns}$ \\
& Fermented & $0.02 \mathrm{~ns}$ & $-0.12 \mathrm{~ns}$ & $-0.25 \mathrm{~ns}$ \\
& Burned & $-0.37 \mathrm{~ns}$ & $-0.10 \mathrm{~ns}$ & $-0.13 \mathrm{~ns}$
\end{tabular}

PSS: preferential sowing season; LSS: late sowing season; * and ** values of $F \leq 0.05$ and $\leq 0.01$ of error probability, respectively; ns: not significant.

Also, for the hybrid 30F53 VYH, which presented a stable behavior for the percentage of fermented grains as a function of $\mathrm{N}$ rate addition, the correlations in PSS between TGW and yield with the percentage of fermented grains were negative (Table 2). This behavior evidences the percentage of fermented grains as a reducer of TGW and yield.

The worst husk coverage of ear, characteristic of hybrids of greater precocity (PANISON et al. 2016), justifies the higher occurrence of fermented grains in AG9025 PRO3 concerning 30F53 VYH. This difference is even more significant when productivity increases. In this case, the increase in the size of the ear and greater filling of grains exposes the grains to the environment even more, which can affect their coloration, justifying the positive correlation between TGW and productivity with the percentage of fermented grains. This behavior does not occur in 30F53 VYH, a hybrid of a higher cycle, which increases TGW and productivity without exposing the grains to the environment because it has better husk coverage.

The hybrid AG9025 PRO3 is classified as moderately tolerant towards fungus infection in the grains, while the hybrid 30F53 VYH is classified as susceptible (PEREIRA FILHO \& BORGHI 2016). This behavior seems to be coherent due to the highest incidence of $F$. verticillioides observed in grains of the hybrid $30 \mathrm{~F} 53$ VYH concerning that found in the hybrid AG9025 PRO3. However, the presence of fungus is not intrinsically related to grain quality. Pathogen presence did not necessarily indicate the existence of damaged grains. A higher severity may be required, that is, a higher internal mycelial growth in the grains to express external characteristics detrimental to grain quality.

\section{CONCLUSION}

The hybrid AG9025 PRO3 presents a higher percentage of fermented grains than the hybrid 30F53 $\mathrm{VYH}$.

The increase in $\mathrm{N}$ rate linearly enhances the percentage of fermented grains of hybrid AG9025 PRO3, and it does not affect these variables of hybrid 30F53 VYH.

The fungus $F$. verticillioides has a higher percentage of incidence in the hybrid 30F53 VYH when compared to the hybrid AG9025 PRO3, as well as at in the late one concerning the preferential sowing 
season.

There is no correlation between the incidence of the fungus $F$. verticillioides and the percentage of fermented grains.

\section{ACKNOWLEDGEMENTS}

To Coordination of Superior Level Staff Improvement (CAPES) and the National Council for Scientific and Technological (CNPq) for granting the scholarship that allowed the development of this study.

\section{REFERENCES}

ALEXANDER NJ et al. 2011. The genetic basis for 3-ADON and 15-ADON trichothecene chemotypes in Fusarium. Fungal Genetics and Biology 48: 485-495.

ANDRIOLLI CF et al. 2016. Timing of fungicide application for the control of Gibberella ear rot of maize. Tropical Plant Pathology 41: 264-269.

BARNETT HL \& HUNTER BB. 1998. Illustrated genera of imperfect fungi. 4.ed. Minnesota: The American Phytopathological Society. 218p.

CASA RT et al. 2007. Incidência de podridões de colmo, grãos ardidos e rendimento de grãos em híbridos de milho submetidos ao aumento na densidade de plantas. Summa Phytopathologica 33: 353-357.

CASA RT et al. 2003. Decomposição dos restos culturais do milho e sobrevivência saprofítica de Stenocarpella macrospora e S. maydis. Fitopatologia Brasileira 28: 355-362.

COELHO AE et al. 2019. Sanidade de híbridos de milho em função da época de semeadura, doses de $\mathrm{N}$ em áreas com e sem rotação de culturas. Colloquium Agrariae 15: 101-113.

DENTI EA \& REIS EM. 2001. Efeito da rotação de culturas, da monocultura e da densidade de plantas na incidência das podridões da base do colmo e no rendimento de grãos de milho. Fitopatologia Brasileira 26: 635-639.

DORDAS C. 2008. Role of nutrients in controlling plant diseases in sustainable agriculture. A review. Agronomy for Sustainable Development 28: 33-46.

DUARTE RP et al. 2009. Comportamento de diferentes genótipos de milho com aplicação foliar de fungicida quanto à incidência de fungos causadores de grãos ardidos. Bioscience Journal 25: 112-122.

FERREIRA DF. 2011. Sisvar: a computer statistical analysis system. Ciência e Agrotecnologia 35: 1039-1042.

JULIATTI FC et al. 2007. Efeito do genótipo de milho e da aplicação foliar de fungicidas na incidência de grãos ardidos. Bioscience Journal 23: 34-41.

MAPA. 2011. Ministério da Agricultura, Pecuária e Abastecimento. Instrução Normativa 60/2011. Disponível em: $<$ http://sistemasweb.agricultura.gov.br/sislegis/action/detalhaAto.do?method=visualizarAtoPortalMapa\&chave $=173957$ 4738>. Acesso em: 01 fev. 2019.

MARIO JL et al. 2003. Reação de híbridos de milho à podridão branca da espiga. Fitopatologia Brasileira 28: 155-158.

MUNKVOLD GP \& DESJARDINS AE. 1997. Fumonisins in Maize: Can we reduce their occurrence? Plant disease 81: 556-565.

NERBASS FR et al. 2015. Field evaluation of maize for Gibberella ear rot resistance using silk channel and kernel inoculation with Fusarium meridionale. Tropical Plant Pathology 40: 388-393.

PANISON F et al. 2016. Harvest time, stem and grain sensibility of maize hybrids with contrasting growth cycles. African Journal of Agricultural Research 11: 2403-2411.

PEREIRA FILHO IA \& BORGHI E. 2016. Mercado de sementes de milho no Brasil Safra 2016/2017. Sete Lagoas: Embrapa. 32p. (Documento 202).

PINTO NFJA. 2005. Grãos ardidos em milho. Sete Lagoas: Embrapa. 6p. (Circular Técnica 66).

POULSEN HORNUM M et al. 2013. Comparación entre técnicas de inoculación de Fusarium verticillioides en espigas de maíz. Revista de Investigaciones Agropecuarias 39: 312-317.

RAMOS DP et al. 2014. Infecção por Fusarium graminearum e Fusarium verticillioides em sementes de milho. Pesquisa Agropecuária Tropical 44: 24-31.

RANZI C et al. 2017. Influence of continuous cropping on corn and soybean pathogens. Summa Phytopathologica 43: 14-19.

REID LM et al. 1999. Interaction of Fusarium graminearum and F. moniliforme in maize ears: Disease Progress, Fungal Biomass, and Mycotoxin Accumulation. Phytophatology 89: 1028-1037.

REIS EM et al. 2011. Controle de doenças de plantas pela rotação de culturas. Summa Phytopathologica 37: 85-91.

RIBEIRO NA et al. 2005. Incidência de podridões de Colmo, grãos ardidos e produtividade de grãos de genótipos de milho em diferentes sistemas de manejo. Ciência Rural 35: 1003-1009.

RITCHIE SW et al. 1993. How a corn plant develops? Ames: lowa State University of Science and Technology. 26p. (Special Report 48).

SANGOI L et al. 2010. Ecofisiologia da cultura do milho para altos rendimentos. Lages: Graphel. 87p.

SARTORI AF et al. 2004. Quantificação da transmissão de Fusarium moniliforme de sementes para plântulas de milho. Fitopatologia Brasileira 29: 456-458.

TRENTO SM et al. 2002. Efeito da rotação de culturas, da monocultura e da densidade de plantas na incidência de grãos ardidos em milho. Fitopatologia Brasileira 27: 609-613. 
WHITE DG. 1999. Compendium Of Corn Diseases. St. Paul: APS Press. American Phytopathological Society. 78p.

WILKE AL et al. 2007. Seed transmission of Fusarium verticillioides in maize plants grown under three different temperature regimes. Plant Disease 91: 1109-1115.

WORDELL FILHO \& SPAGNOLLO IE. 2013. Sistema de cultivo e doses de nitrogênio na sanidade e no rendimento do milho. Ciência Rural 43: 199-205.

YATES IE et al. 2005. Desempenho em campo de milho cultivado a partir de sementes inoculadas com Fusarium verticillioides. Micopatologia 159: 65-73. 